\title{
Eco-hydrological impacts of Eucalyptus in the semi humid Ethiopian Highlands: the Lake Tana Plain
}

\author{
Tilashwork Chanie ${ }^{1}$, Amy S. Collick ${ }^{2 *}$, Enyew Adgo ${ }^{3}$, C. Johannes Lehmann ${ }^{4}$, \\ Tammo S. Steenhuis ${ }^{5}$ \\ ${ }^{1}$ Cornell University Master's Program in Integrated Watershed Management and Hydrology Cornell University at Bahir Dar. Currently at: \\ Amhara Regional Agricultural Research Institute Debre Berhan, Ethiopia. \\ ${ }^{2}$ Pasture Systems and Watershed Management Research Unit, Agricultural Research Service, USDA, University Park, Pennsylvania, \\ 16802, USA. \\ ${ }^{3}$ Faculty of Agriculture, University of Bahir Dar, Bahir Dar, Ethiopia. \\ ${ }^{4}$ Department of Crop and Soil Sciences, Cornell University, Ithaca, NY, 14853, USA. \\ ${ }^{5}$ Department of Biological and Environmental Engineering, Cornell University, Ithaca, NY, 14853, USA, and Department of Civil and \\ Water Resources Engineering, Institute of Technology, Bahir Dar University, Bahir Dar, Ethiopia. \\ *Corresponding author. E-mail: Amy.Collick@ars.usda.gov
}

\begin{abstract}
Eucalyptus is the tree of choice for wood production by farmers in Ethiopia. Although there are many claims about its harmful effect on ecology and water availability, little actual research exists. The main objective of this study was, therefore, to study the extent of harm of Eucalyptus on the ecosystem. This study was conducted at the Koga Watershed near Lake Tana in Ethiopia. Twenty-five farmers were interviewed and a field experiment with three replications was carried out to quantify the effect of Eucalyptus on various soil physical and chemical properties and maize crop measurements and to compare bulk density, soil moisture contents, maize crop counts and shading effects in fields bordered by Eucalyptus and Croton macrostachyus. Our results show that Eucalyptus decreased both soil nutrients and maize yields within $20 \mathrm{~m}$ of the trees. Although moisture content was not affected during the monsoon, it decreased faster within $30 \mathrm{~m}$ of the Eucalyptus trees than elsewhere. Soils become water repellent, too. Local farmers' perception agreed with our experimental findings and indicated that Eucalyptus trees are exhausting the once productive land. They also reported that Eucalyptus dries up springs. Despite this, the growers insist on planting Eucalyptus because of its cash income.
\end{abstract}

Keywords: Eucalyptus; Soil water repellency; Croton machrostachyus; Koga watershed.

\section{INTRODUCTION}

Globally, more than 80 countries have planted more than 4 million hectares of Eucalyptus. It is fast growing, requires minimal upkeep, grows up from its roots and has easily collected seeds and is desirable for lumber, construction and fuelwood. Therefore, Eucalyptus has become one of the most planted tree species in Africa in recent years.

In Ethiopia Eucalyptus was introduced in either 1894 or 1895 because of the massive deforestation around Addis Ababa for firewood (Pankhurst, 1961). Since then, shortages in fuel wood supplies and a need for long-term economic returns on farmers' land have made Eucalyptus very attractive. Eucalyptus is commonly planted in a farmer's cropland plot or on boundaries of cropland. In addition, they are grown on marginal lands and in some cases they are planted to stabilize gullies in wet areas.

Although quantitative evidence is scanty, there has been a perception that planting Eucalyptus adversely affects crop productivity (Kidanu et al., 2005). Lane et al. (2004) described that in China, the expansion of Eucalyptus plantations on lands previously used for crops and occupied by indigenous trees and grass lowered water tables and reduced water availability for irrigation due to soil hydrophobicity (water repellency) and its deep and dense root network. Eucalyptus seedlings are vulnerable to severe water stress unlike the seedlings of indigenous deciduous tree species in Ethiopia (Gindaba et al., 2004). This shows that Eucalyptus trees need more water and compete with neighboring plants for the available water in the soil. El-Amin et al. (2001) in Sudan reported that Eucalyptus caused crop yield reduction due to nutrient depletion and production of toxic exudates (allelochemicals). Finally, nutrients are exported out from the plantation's soil system by removing trees for timber sales and fuel wood (Holgén and Svensson, 1990).

The environmental impacts of vegetation on the hydrology have been studied only to a limited extent in Ethiopia and eastern Africa (Bayabil et al., 2010). This is especially true for Eucalyptus trees as discussed above. Therefore, this study examines the effect of Eucalyptus on soil physical and chemical properties, light intensity, and root distribution. The study also compares the density of undergrowth, moisture content and crop performances up to $40 \mathrm{~m}$ from the tree stands of two common plantation types, Eucalyptus stand and C. macrostach$y u s$, trees used for shade coffee.

\section{MATERIALS AND METHODS Study area}

The Koga Watershed, a 28,000 ha watershed, was selected for this study because of the presence of the Koga Watershed Irrigation and Watershed Management project. It consists of a 7,000 ha command area for irrigation agriculture and an environmental management plan for reducing upstream erosion, and it has been supported by the African Development Bank (ADB) and the Ethiopian government. The catchment area is located between $11^{\circ} 10^{\prime} \mathrm{N}$ to $11^{\circ} 25^{\prime} \mathrm{N}$ latitude and $37^{\circ} 02^{\prime} \mathrm{E}$ to $37^{\circ}$ $17^{\prime}$ E longitude and ranges from 1800 to $3200 \mathrm{~m}$ in elevation. It 
has a mean annual rainfall of $1560 \mathrm{~mm}$ and mean daily temperatures range between 16 and $20^{\circ} \mathrm{C}$.

The dominant soil type in the study area is nitisol (FAO, 2001). This soil is fertile, deep, porous and well drained. In addition, it has a stable soil structure permitting deep rooting, and it resists erosion. On this productive soil throughout the study area, farmers grow coffee, maize, finger millet, teff, (Eragrostis tef) niger seed (Guizotia abyssinica), lupine, legumes and vegetables (see Fig. 2). Due to its fast growth and low-input upkeep, Eucalyptus is planted along cropland borders and the main road for fuel wood and construction timbers, ultimately to generate income (Jagger and Pender, 2003). Although less common, Croton machrostachyus trees also are planted along cropland borders and as shade in coffee plantations. Indigenous trees are nearly absent due to intensive deforestation.

This study was carried out on Eucalyptus and $C$. machrostachyus plantations bordering maize crop fields. Maize is the major crop, and it performs well on nitisols (FAO, 2001). The maize variety, BH540, grows in these fields. It is late maturing, has good grain filling capability, and characterized by reddish tassels. Spacing between plants and between rows is 30 $\mathrm{cm}$. One-hundred $\mathrm{kg}$ DAP and $50 \mathrm{~kg}$ urea per hectare were applied at sowing and vegetative stages, respectively. According to the development agents and local farmers, growers could harvest greater than 5 tons ( 50 quintals) per hectare with a sale price of about 600 Ethiopian birr (\$55) per $100 \mathrm{~kg}$ in 2008 .

\section{Data collection and analysis}

The experiment was carried out in three maize fields bordered by Eucalyptus and Croton machrostachyus plantations. Soil samples were taken from a single depth $(0-20 \mathrm{~cm})$ or from three profile depths $(0-20,20-40$ and $40-60 \mathrm{~cm})$ at varying distances $(0.5,1,2,5,10,15,20,40$ meters) away from the border plantations. The data collected at the $40 \mathrm{~m}$ distance were used as the control value. Crop biomass and root samples and shading effects were obtained at the same distances away from the plantations while undergrowth density counts were conducted along transects under varying canopy densities in the tree plantations (Table 1). The measurements within crop fields compared between those adjacent to Croton macrostachyus and to Eucalyptus were bulk density, moisture content (September only), maize plant height, maize plant count and undergrowth density.

Statistical differences between distances within the same field, between fields, and between those fields adjacent to $E u$ calyptus and C. machrostachyus were determined by one-way ANOVA employing a 95\% level of confidence. Besides sampling, interviews were carried out with 25 farmer representatives.

Farmer perception of Eucalyptus: The general impact and perception of Eucalyptus trees on crop production, soil properties and moisture storage was assessed through interviews with key informants. Twenty-five active farmers were interviewed in two representative kebeles (Ambomesk and Enguty), dominated by Eucalyptus plantations. The primary purpose of these interviews was to gather information concerning the history and background of Eucalyptus and to provide direction concerning the fundamental issues and questions to be answered experimentally.

Analyses of soil physical and chemical properties: The schedule of testing for the physical and chemical properties for both the Eucalyptus and Croton macrostachyus at various distances from the trees is shown in Table 1. Fig. 2 includes pho- tos of both C. macrostachyus (A and C) and Eucalyptus spp (B and D). To determine the soil physical and chemical properties below both Eucalyptus and Croton macrostachyus plantations, different soil properties were analysed from samples obtained at $0-20 \mathrm{~cm}$ soil depths and distance from the selected plantations (Table 1). Texture (\%), soil $\mathrm{pH}$ (both $\mathrm{KCl}$ and $\mathrm{H}_{2} \mathrm{O}$ ) in moles $\mathrm{L}^{-1}$, organic matter content (\%), available phosphorus $\left(\mathrm{mg} \mathrm{kg}^{-1}\right)$, total nitrogen $(\%)$, exchangeable calcium and potassium $(\mathrm{cmol}$ (+) $\mathrm{kg}^{-1}$ soil) were analyzed from samples obtained from a depth between 0 and $20 \mathrm{~cm}$ and at $0.5,1,2,5,10,15,20,40$ meters from the selected Eucalyptus plantations in July 2008. The percentages of sand, silt and clay were determined using particle-size or mechanical analysis for air-dried soil samples as described by Rowell (1994). The pH was measured potentiometrically using a digital $\mathrm{pH}$ meter in the supernatant suspension of $1: 2.5$ soil to liquid ratio where the liquids were water and $1 \mathrm{M} \mathrm{KCl}$ whereas the percentages of organic matter (OM) and total nitrogen (TN) were determined by titration methods by Walkley-Black (WB) (1934) and Kjeldahl (Cohen, 1910), respectively. Exchangeable bases such as calcium and potassium were extracted from the soil colloids with $1 \mathrm{M}$-ammonium acetate at pH 7 (Sahlemeden and Taye, 2000). Then, exchangeable $\mathrm{Ca}$ was measured from the extracts using an atomic absorption spectrophotometer while exchangeable $\mathrm{K}$ was determined from the same extracts with flame photometer as described by Rowell (1994). Finally, available P was determined by Olsen extraction method (Olsen et al., 1954, Table 1).

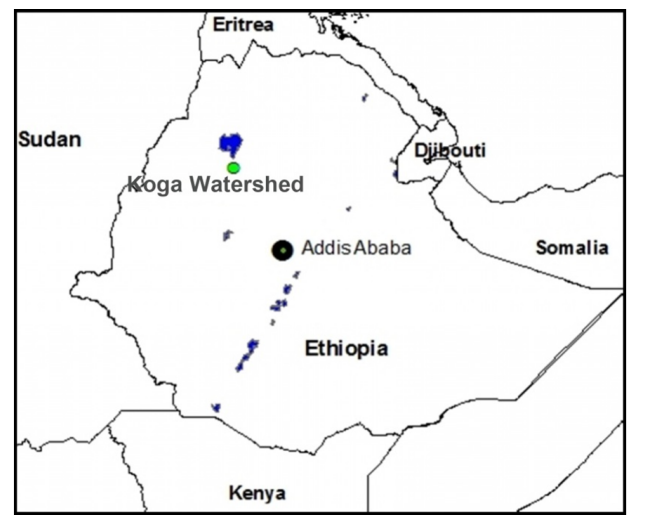

Fig. 1. Location of the Koga watershed.
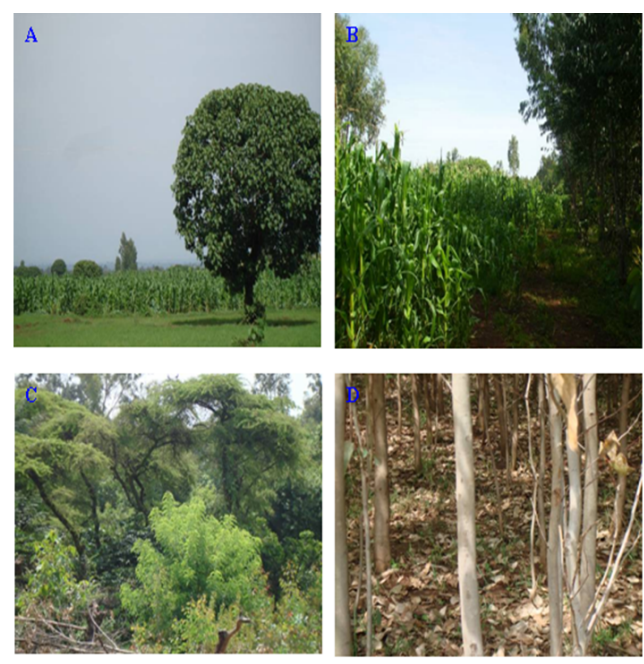

Fig. 2. Croton macrostachyus (A) and Eucalyptus (B) trees along maize farm borders, and the under growth density within a coffee garden (C) and a Eucalyptus stand (D). 
Table 1. Soil physical, chemical and biological parameters and sampling strategies.

\begin{tabular}{|c|c|c|c|c|c|}
\hline \multirow{2}{*}{ Parameter } & \multicolumn{2}{|c|}{ Sampling distances $(\mathrm{m})$ from trees } & \multirow{2}{*}{$\begin{array}{l}\text { Sampling depths } \\
(\mathrm{cm})\end{array}$} & \multirow{2}{*}{$\begin{array}{c}\text { Sampling } \\
\text { dates }\end{array}$} & \multirow{2}{*}{$\begin{array}{l}\text { Methods used for } \\
\text { analysis }\end{array}$} \\
\hline & Eucalyptus & C. macrostachyus & & & \\
\hline Texture (\%) & $\begin{array}{c}0.5,1,2,5,10,15 \\
20,40\end{array}$ & No sampling & $0-20$ & July & $\begin{array}{c}\text { particle-size or } \\
\text { mechanical analysis } \\
\text { method (Rowell,1994) }\end{array}$ \\
\hline Bulk density $\left(\mathrm{g} \mathrm{cm}^{-3}\right)$ & $\begin{array}{c}0.5,1,2,5,10,15 \\
20,40\end{array}$ & $\begin{array}{c}0.5,1,2,5,10 \\
15,20,40\end{array}$ & $\begin{array}{c}0-20,20-40 \\
40-60 \\
\end{array}$ & July & $\begin{array}{c}\text { Tube core method } \\
\text { (Blake,1965) }\end{array}$ \\
\hline \multirow{4}{*}{ Moisture content (\%) } & $1,5,10,15,20,40$ & No sampling & $\begin{array}{c}0-20,20-40 \\
40-60\end{array}$ & July & \multirow{4}{*}{ Gravimetric method } \\
\hline & $1,5,10,15,20,40$ & No sampling & $\begin{array}{c}0-20,20-40 \\
40-60\end{array}$ & August & \\
\hline & $0.5,1,2,5,10,15,20$ & $\begin{array}{c}0.5,1,2,5,10 \\
15,20\end{array}$ & $\begin{array}{c}0-20,20-40 \\
40-60\end{array}$ & September & \\
\hline & $\begin{array}{c}0.5,1,2,5,10,15 \\
20,40\end{array}$ & No sampling & $\begin{array}{c}0-20,20-40 \\
40-60\end{array}$ & October & \\
\hline $\begin{array}{l}\text { Available water capaci- } \\
\text { ty }(\%)\end{array}$ & $\begin{array}{c}0.5,1,2,5,10,15 \\
20,40\end{array}$ & No sampling & $0-20$ & October & Klute (1965) \\
\hline $\begin{array}{l}\text { Soil } \mathrm{pH} \text { (by both } \mathrm{KCl} \\
\text { and } \mathrm{H}_{2} \mathrm{O} \text { ) in mole } \mathrm{L}^{-1}\end{array}$ & $1,5,10,15,20,40$ & No sampling & $0-20$ & July & $\begin{array}{c}\text { By a suspension of } \\
1: 2.5 \text { soil to water and } \\
1 \mathrm{M} \mathrm{KCl}\end{array}$ \\
\hline Organic matter $(\%)$ & $1,5,10,15,20,40$ & No sampling & $0-20$ & July & $\begin{array}{c}\text { Walkley-Black (WB) } \\
\text { titration method }\end{array}$ \\
\hline Total nitrogen $(\%)$ & $1,5,10,15,20,40$ & No sampling & $0-20$ & July & $\begin{array}{c}\text { Kjeldahl titration } \\
\text { method }\end{array}$ \\
\hline $\begin{array}{l}\text { Available phosphorus } \\
\left(\mathrm{mg} \mathrm{kg}^{-1}\right)\end{array}$ & $1,5,10,15,20,40$ & No sampling & $0-20$ & July & $\begin{array}{c}\text { Olsen extraction (Ol- } \\
\text { sen et al., 1954) }\end{array}$ \\
\hline $\begin{array}{l}\text { Exchangeable calcium } \\
\left(\mathrm{cmol}^{(+)} \mathrm{kg} \mathrm{soil}^{-1}\right)\end{array}$ & $1,5,10,15,20,40$ & No sampling & $0-20$ & July & $\begin{array}{c}\text { Extraction, atomic } \\
\text { absorption spectropho- } \\
\text { tometer (Rowell,1994) }\end{array}$ \\
\hline 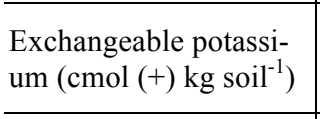 & $1,5,10,15,20,40$ & No sampling & & July & $\begin{array}{c}\text { Extraction with flame } \\
\text { photometer (Rowell, } \\
1994)\end{array}$ \\
\hline $\begin{array}{l}\text { Water repellency for } \\
\text { field dried, air dried \& } \\
\text { wet soils (seconds) }\end{array}$ & $\begin{array}{c}0,20,40,60,80,100, \\
120,140,160,180, \\
200,220,240,260, \\
280,300 \mathrm{~cm}\end{array}$ & No sampling & $0-20$ & July, October & \multirow{2}{*}{$\begin{array}{c}\text { water drop penetration } \\
\text { time (WDPT) test } \\
\text { method (Dekker and } \\
\text { Ritsema,1995) }\end{array}$} \\
\hline $\begin{array}{l}\text { Water repellency of } \\
\text { leaf, bark root (se- } \\
\text { conds) }\end{array}$ & 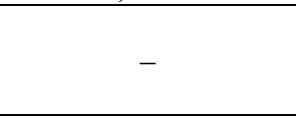 & No sampling & N/A & October & \\
\hline Shading effect & $\begin{array}{c}0,0.51,2,5,10,15, \\
20,40\end{array}$ & No sampling & N/A & September & $\begin{array}{l}\text { Direct measurement } \\
\text { using light meter }\end{array}$ \\
\hline Maize plant height $(\mathrm{cm})$ & $1,5,10,15,20,40$ & $\begin{array}{c}1,5,10,15,20 \\
40\end{array}$ & N/A & September & Direct measurement \\
\hline $\begin{array}{l}\text { Maize plant count (no. } \\
\mathrm{ha}^{-1} \text { ) }\end{array}$ & $1,5,10,15,20,40$ & $\begin{array}{c}1,5,10,15,20 \\
40\end{array}$ & N/A & September & Direct counting \\
\hline Maize yield $\left(\mathrm{kg} \mathrm{ha}^{-1}\right)$ & $1,5,10,15,20,40$ & No sampling & N/A & September & Direct weighing \\
\hline Maize biomass $\left(\mathrm{kg} \mathrm{ha}^{-1}\right)$ & $1,5,10,15,20,40$ & No sampling & $\mathrm{N} / \mathrm{A}$ & September & Direct weighing \\
\hline $\begin{array}{l}\text { Root distribution (no. } \\
\mathrm{ha}^{-1} \text { ) }\end{array}$ & $1,5,10$ meter & No sampling & $\begin{array}{c}0-20,20-40 \\
40-60\end{array}$ & September & $\begin{array}{l}\text { Profile pits and direct } \\
\text { counting }\end{array}$ \\
\hline $\begin{array}{l}\text { Under growth density } \\
\left(\text { no. } \mathrm{ha}^{-1}\right)\end{array}$ & Under the shade & Under the shade & N/A & & \\
\hline
\end{tabular}

While soil moisture depicts the water in the soil, the level of water repellency in the soil indicates the capacity of the soil to wet up. Water repellency has been often associated with soils under Eucalyptus trees. In July when the soils were wet, we sampled soils along transects in the different plantations for their level of water repellency. The water repellency of the soil was analyzed on field, air-dried and wetted soil samples collected at various distances $(0,20,40,60,80,100,120,140$, $160,180,200,220,240,260,280,300 \mathrm{~cm})$ away from the Eucalyptus plantations using the water drop penetration time (WDPT) test described by Dekker and Ritsema (1995). In addi- tion, soil water repellency was determined on a collection of the leaves, bark and roots from Eucalyptus trees to resolve the wetting capacity of the tree litter on the plantation floor.

Soil samples for bulk density, moisture content and Eucalyptus root distribution were taken from three profile depths at each distance interval while the remaining parameters were sampled from the $0-20 \mathrm{~cm}$ profile at each distance.

Available water capacity (AWC, \%) was analyzed at field capacity (FC, 0.33 bars) and permanent wilting point (PWP, 15 bars) (Klute, 1965) from three samples obtained in the soil profile between 0 and $20 \mathrm{~cm}$ depth and at $0.5,1,2,5,10,15$, 
20, $40 \mathrm{~m}$ away from the selected plantations in October 2008. Gravimetric soil moisture content (\%) was determined from soil samples taken from depths, $0-20,20-40$ and $40-60 \mathrm{~cm}$ and at distances of 1, 2, 5, 10, 15, 20, $40 \mathrm{~m}$ in July and August 2008 and at distances of $0.5,1,2,5,10,15,20,40 \mathrm{~m}$ in September and October 2008 (Table 1). The different sampling months represented vegetative, flowering, tasseling and grain filling stages, respectively, of the maize crop. Moisture content was determined for soils in fields adjacent to Eucalyptus for all four sampling months while it was only determined in September in those soils adjacent to $C$. machrostachyus. Bulk density was determined using tube core method described in Blake (1965) from soil samples collected from the soil profile at three depths $(0-20,20-40$ and $40-60 \mathrm{~cm})$ and at distances of $0.5,1,2,5$, 10, 15, 20, 40 meters into maize fields adjacent to both Eucalyptus and C. macrostachyus plantations in July 2008 (Table 1).

Shading and undergrowth density: Shading (lux) effect was measured using a light meter at multiple times throughout a day $(9: 00 \mathrm{am}, 12: 00 \mathrm{pm}, 12: 30 \mathrm{pm}, 3: 00 \mathrm{pm}$ and $4: 00 \mathrm{pm})$ at the edge of the Eucalyptus plantations and crop field and in the maize field (above the canopy of the maize plants) at $0.5,1,2$, $5,10,15,20,40 \mathrm{~m}$ away from the trees. Light intensity is a critical growth factor for neighboring crops and undergrowth vegetation. Therefore, in addition to shading intensity, the density of undergrowth vegetation (no. ha ${ }^{-1}$ ) growing in very sparse, sparse, dense and very dense canopied areas within Eucalyptus and C. macrostachyus plantations was also estimated by totaling the number of individual shrubs, herbs, climbers and others (less than $3 \mathrm{~m}$ in height) in $3 \mathrm{~m} \times 3 \mathrm{~m}$ sampling points in each canopy condition along three transects in each plantation.

Maize plant measurements: Plant measurements, such as height, count, biomass, root distribution and yield, were conducted on the maize plants directly adjacent to the tree plantations. In September 2008, near the time of harvest, the number of plants (no. ha ${ }^{-1}$ ) and the plant height $(\mathrm{cm})$ of individual maize plants were recorded at three sampling areas of $4 \mathrm{~m}^{2}$ (2 $\mathrm{m} \times 2 \mathrm{~m})$ per distance $(1,5,10,15,20$ and $40 \mathrm{~m})$ in fields adjacent to both Eucalyptus and C. macrostachyus.

The above-ground plant biomass $\left(\mathrm{kg} \mathrm{ha}^{-1}\right)$ of Eucalyptus plants adjacent to Eucalyptus was determined at three sampling points at each distance: $1,5,10,15,20,40 \mathrm{~m}$ from the tree plantation edge. Furthermore, the root distribution (no. ha ${ }^{-1}$ ) of maize plants was also determined at $0-20,20-40$ and $40-60$ $\mathrm{cm}$ depths in three sampling pits at each distance of 1,5 and 10 $\mathrm{m}$ from the Eucalyptus plantation edge. The sampling pits measured $1 \mathrm{~m}$ in length by $0.2 \mathrm{~m}$ wide. At harvest time, the yield $\left(\mathrm{kg} \mathrm{ha}^{-1}\right)$ from three sampling locations at each distance 1 , $5,10,15,20$ and $40 \mathrm{~m}$ from the tree plantations was recorded.

\section{RESULTS}

\section{Farmers' perception about the environmental impact of Eucalyptus plantation}

Twenty-five respondents, all male, were interviewed and ranged in age from 36 to 45 years old with education levels varying from illiterate and non-formal education to grade eight or higher. Female respondents were not involved in the interviews since they were less familiar with the day-to-day agricultural activities, and there was little exchange of information from males to females even in the same household. Sixty percent of the respondents had attended at least grade 1 while only $12 \%$ continued beyond fourth grade. All respondents possessed land ranging from 0.25 to 3 hectares with half of them owning farms of 0.25 to 1 ha size. All landowners utilized their land for a combination of crop production, tree plantation and grazing.

Tree planting in the area was intended for fuel wood (100\%), income generation (96\%) and construction (84\%). Environmental conservation was not indicated as an intention of planting. The most commonly planted tree species in the Koga Watershed was Eucalyptus, the planting of which began during the reign of Emperor Haile Selassie (1915-1974) with a very fast expansion rate since 1991 (Table 2). The Eucalyptus trees were planted on former cropland $(40 \%)$ and along cropland borders $(60 \%)$ and the majority on marginal lands (Table S1). The area on the farm covered by trees was usually between 0.15 and 0.25 ha. The few large farms had plantings in the 1-2 ha range (Table S1). In the watershed, all farmers perceived that Eucalyptus plantations have a negative environmental impact because of the shading effect, water and nutrient competition, thinning of seedlings and forcing poor grain filling $(100 \%)$. Almost half of the local farmers professed that there is no difference between crops species in resisting the negative effect, i.e. all are susceptible (Table S2). According to farmer opinion, the Eucalyptus trees affected soil property by drying out the soil (92\%), making soil unfertile (8\%) and reddish (4\%). Most farmers $(96 \%)$ in the watershed suggested that Eucalyptus trees affect soil moisture through excessive root suction. Soil moisture stores dried up due to the nearby Eucalyptus plantation (80 \%) (Table S3). The responses from the interviewees showed that Eucalyptus trees adverse effects are more pronounced on reddish soil (96\%), sloping land (84\%), and dry land (96\%) instead of on black soil, flat and wet lands. It is interesting that according to the view of the respondents, the most adverse effects of Eucalyptus can be seen if the trees are planted east and least if planted north $(20 \%)$ of the cropland (Table 3$)$.

Table 2. Farmers' perception concerning tree planting in the locality $(\mathrm{N}=25)$. Eucalyptus plantations were begun either during the reign of Emperor Haile Selassie (1915 - 1974) or Mengistu Haile Mariam (1974 - 1987).

\begin{tabular}{|c|c|c|c|c|}
\hline $\begin{array}{l}\text { Issues regarding to trees } \\
\text { planting }\end{array}$ & \multicolumn{4}{|c|}{$\%$ of farmer respondents in parenthesis } \\
\hline Source of energy in the area & $\begin{array}{l}\text { Wood } \\
(100)\end{array}$ & \multicolumn{2}{|c|}{$\begin{array}{l}\text { Manure } \\
(12)\end{array}$} & $\begin{array}{l}\text { Others } \\
(12)\end{array}$ \\
\hline $\begin{array}{l}\text { Purpose of tree planting in } \\
\text { study area }\end{array}$ & $\begin{array}{l}\text { For fuel } \\
(100)\end{array}$ & Income (96) & $\begin{array}{c}\text { Construction } \\
(84)\end{array}$ & $\begin{array}{l}\text { Others } \\
\text { (4) }\end{array}$ \\
\hline Mostly planted tree & \multicolumn{2}{|c|}{ Eucalyptus (100) } & \multicolumn{2}{|c|}{ Others $(0)$} \\
\hline $\begin{array}{l}\text { Start of Eucalyptus planta- } \\
\text { tion }\end{array}$ & \multicolumn{2}{|c|}{ During emperor Mengistu (36) } & \multicolumn{2}{|c|}{$\begin{array}{l}\text { Haile Selassie } \\
\text { (64) }\end{array}$} \\
\hline $\begin{array}{l}\text { Eucalyptus plantation expan- } \\
\text { sion }\end{array}$ & $\begin{array}{c}\text { Very fast } \\
(56)\end{array}$ & $\begin{array}{l}\text { Fast } \\
(24)\end{array}$ & $\begin{array}{l}\text { Average } \\
\text { (12) }\end{array}$ & $\begin{array}{c}\text { Slowly } \\
(8)\end{array}$ \\
\hline
\end{tabular}


Table 3. Conditions at which the farmers perceive the effect of Eucalyptus plantations is more pronounced $(\mathrm{N}=25)$ according to perceptions of the farmers.

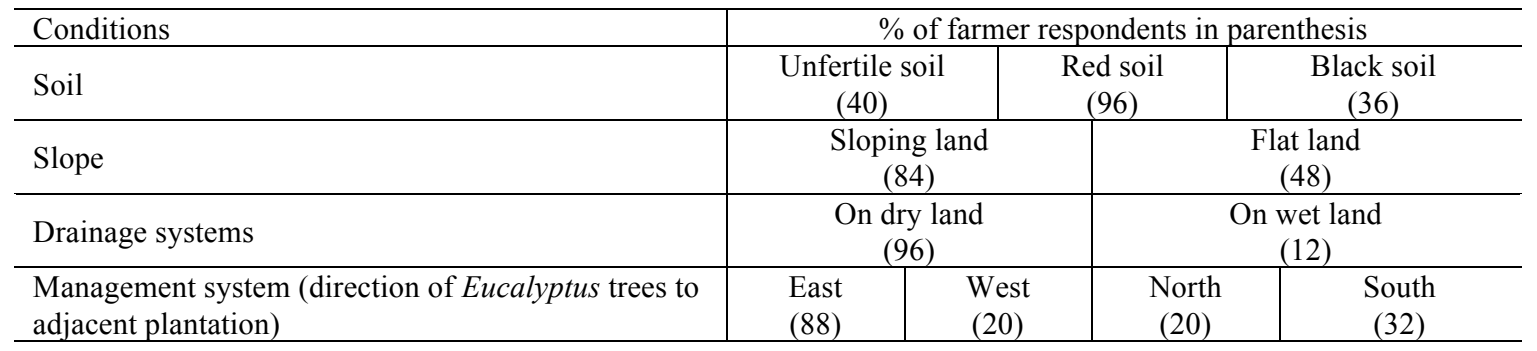

\section{Experimental findings about the effect of Eucalyptus plantation on the ecosystem}

Soil physical properties: In both texture and bulk density comparisons of soils at different distances and depths, nonsignificant differences were detected. The soil textural classes for all soil samples taken in $0-20 \mathrm{~cm}$ depth and all distances in the study area were clay loam (Table S4). The remainder of the profile was also clay loam. Because of the volcanic origin of the soils, all the bulk densities at all depths and distances from Eucalyptus and C. macrostachyus stands were low and ranged from 1.0 to $1.1 \mathrm{~g} \mathrm{~cm}^{-3}$. Eucalyptus trees did not affect organic matter content in the soil significantly. The organic matter varied from $2-4 \%$ with an average of approximately $3 \%$ (Fig. S1).

Soil chemical properties: In the study area, the surface soils (in $0-20 \mathrm{~cm}$ depth) were very acidic and did not significantly differ ( $\mathrm{p}>0.05)$ with distance to the Eucalyptus stand (Fig. S2). Although not significant, the $\mathrm{pH}$ value at $5 \mathrm{~m}$ from the tree was the lowest after intense rains. Unlike $\mathrm{pH}$, there were significant differences in macronutrient concentration with distance from Eucalyptus tree (Fig. 3). In general, the macronutrient status increased with distance from the Eucalyptus stand. Total N (TN), nearest to the Eucalyptus stand however, was significantly $(\mathrm{p}<0.001)$ above average. Next to it at $5 \mathrm{~m} \mathrm{TN}$ was at its minimum (Fig. 3A). Farther from the trees at $40 \mathrm{~m}$, it increased up to the same value as the values at $1 \mathrm{~m}$ from the trees. Although the overall available P content of the fields' soil was in the very low range $\left(<5 \mathrm{mg} \mathrm{kg}^{-1}\right)$, the one-way ANOVA showed that there was a highly significant difference $(\mathrm{P}<0.001)$ in an upward trend with distance from the Eucalyptus stand (Fig. 3B). Exchangeable $\mathrm{Ca}$ concentrations, at $1 \mathrm{~m}$ distance was 7.8 cmol per $\mathrm{kg}$ of soil and significantly $(\mathrm{P}<0.05)$ less than the values at the other sampling points along the transect (Fig. 3C) which were in range that was considered in the high range $(10-$ $-20 \mathrm{cmol}$ per $\mathrm{kg}$ of soil) in Ethiopia. Finally, the exchangeable $\mathrm{K}$ concentrations at all distances were in high range, and independent of distance to the Eucalyptus stand at the 5\% significant level (Fig. 3D).

Moisture contents: In July and August when it rains almost continuously, there was not a significant difference between moisture contents at the various distances from the Eucalyptus stand (Fig. 4A and 4B). Only in the $40-60 \mathrm{~cm}$ depth in July, the moisture content at $5 \mathrm{~m}$ from the tree was significantly lower than values at 1 and $40 \mathrm{~m}$. In September, at the end of the monsoon period, the moisture content measurements near the Eucalyptus stand at all three depths were significantly less $(\mathrm{p}<$ 0.001) than the moisture contents farther away (Fig. 4C). This trend was not observed for C. macrostachyus where no significant difference in moisture content was observed with increasing distance from the trees. Interestingly, at $15 \mathrm{~m}$ and greater from the trees, the moisture contents near the
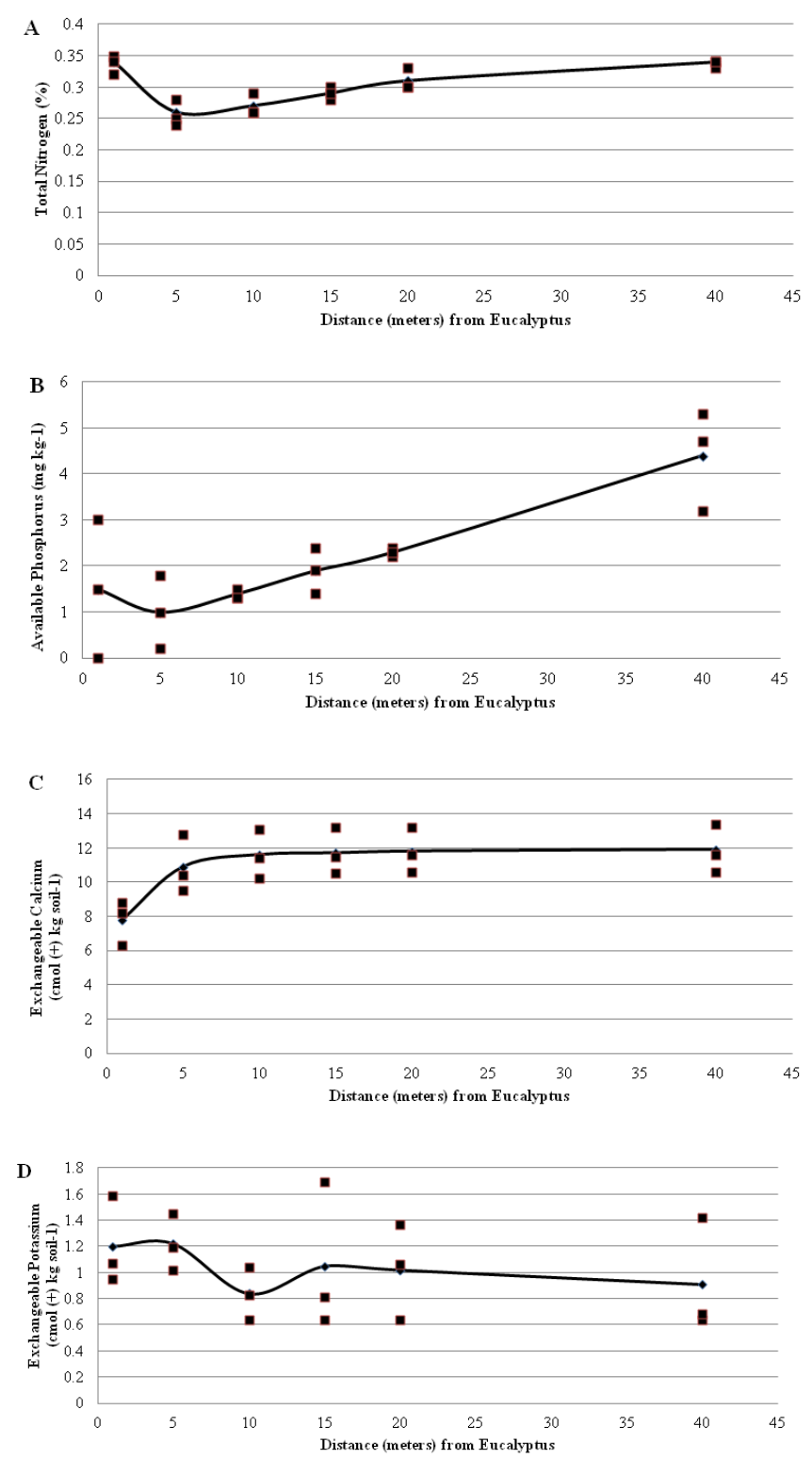

Fig. 3. Percentage of available phosphorus (A) total nitrogen (B) exchangeable calcium (C) and exchangeable potassium (D). All samples from each distance and field were graphed.

Eucalyptus stand showed no statistical difference from those moisture contents near the C. macrostachyus stands (Fig. 5). In October, at the maize grain filling stage, the trend in moisture content at increasing distances from the Eucalyptus trees was similar to that in Sepember with moisture contents near the Eucalyptus stand significantly $(\mathrm{p}<0.001)$ less than those 


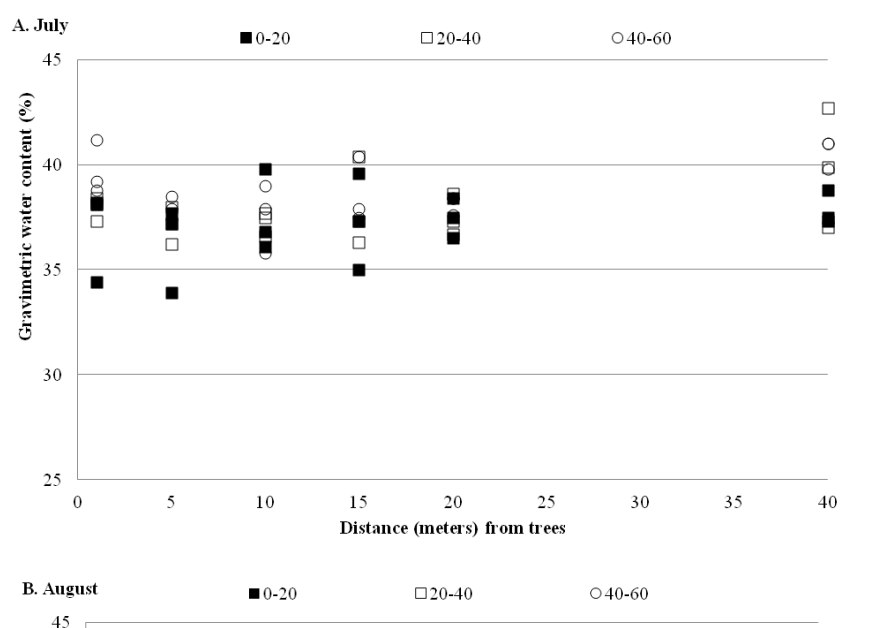

further away (Fig. 4C). In addition for this month, the moisture content in the $0-20 \mathrm{~cm}$ depth was significantly less than the moisture contents in $20-40$ and $40-60 \mathrm{~cm}$ depths.

Water repellency of soil: Under these wet conditions, the soils were wettable with WDPT value $<4$ s (Table 4 ). However, when the soils were air or oven dried, they became highly hydrophobic especially close to the Eucalyptus stand as shown by the WDPT test $(\mathrm{P}<0.001)$. The WDPT test showed that for the field-dried soils at 0 to $80 \mathrm{~cm}$ from the trees, the soils were severely water repellent, from 100 to $160 \mathrm{~cm}$ strongly water repellent, from 180 to $220 \mathrm{~cm}$ slightly water repellent and over $240 \mathrm{~cm}$, non-water repellent. For the air-dried soil, the same trend was observed but water repellency was less severe. The dried Eucalyptus plant parts (leaf, bark and root) were found to be slightly water repellent. The WDPT value of the leaf was significantly $(\mathrm{P}<0.001)$ greater than the values of bark and root.

Light intensity: Highly significant difference $(\mathrm{p}<0.001)$ in light intensity at different distances from the Eucalyptus stand was found for all measurement times. The trees caused serious light intensity reduction up to 5 and $10 \mathrm{~m}$ distances at 9:00am and 12:00am in the west direction, up to $10 \mathrm{~m}$ at $12: 30 \mathrm{pm}$ in the north and up to $15 \mathrm{~m}$ at 3:00pm in the east direction (Fig. 6).

Root distribution: The Eucalyptus root was significantly ( $p$ $<0.001$ ) more dense at 5 meter from the tree than at either $1 \mathrm{~m}$ or $10 \mathrm{~m}$ (Table 5). At $5 \mathrm{~m}$ distance, 600 roots per square meter were counted over the first $60 \mathrm{~cm}$ of the profile. That means that there was one root in every $1.8 \mathrm{~cm}^{2}$. The variation of root density over the first $60 \mathrm{~cm}$ in depth was not significant.

Crop performance: The number of plants and plant height is given as function of distance from the tree for both the Eucalyptus and C. macrostachyus spp. (Fig. 7A and 7B). Obviously, the crop was not affected by the proximity of the Croton spp. while the effect on the maize near the Eucalyptus faired much worse than farther away. There was a similar trend for both the maize yield and the biomass as a function of distance to the Eucalyptus stand (Fig. 7C). There was a 10-fold difference in biomass for the 1 and $20 \mathrm{~m}$ sampling points. The yield and biomass between 20 and $40 \mathrm{~m}$ was not significantly different.

Undergrowth status of shade trees: The average undergrowth density of the coffee garden (C. machrostachyus) plantation was significantly $(\mathrm{P}<0.01)$ greater than that of under Eucalyptus trees (Fig. S4). Although the undergrowth density under both species of tree plantations decreased as the canopy closure increased, the undergrowth density in the $C$. machrostachyus stand is greater than that of the Eucalyptus stand at all the different densities of the canopy.

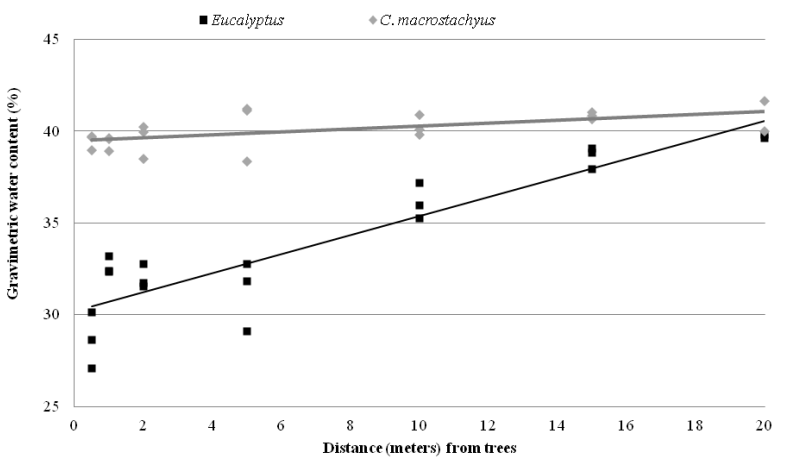

$\mathrm{cm}$ and $40-60 \mathrm{~cm}$ sampling depths at increasing distance Eucalyptus stands in July (A), August (B), September (C) and October (D) 2009. All samples at each depth and each distance graphed.

Fig. 5. Comparison of gravimetric moisture content averaged over three profile depths at increasing distances from Eucalyptus (black line with black squares) and C. macrostachyus (gray line with gray diamonds). 
Table 4. Persistence of water repellency (WDPT (s)) of the soil at different distances from Eucalyptus stand for soils in the field and sampled soils in the lab in July and October.

\begin{tabular}{|c|c|c|c|}
\hline \multirow{2}{*}{$\begin{array}{c}\text { Sampling } \\
\text { Distance }(\mathrm{cm})\end{array}$} & \multicolumn{3}{|c|}{ WDPT values (seconds) } \\
\hline & Field dry soils & Air-dried soils samples & Wetted soils samples \\
\hline $\mathrm{T} 1(0 \mathrm{~cm})$ & $2740 \mathrm{a} * * *$ & $110.7 \mathrm{a} * *$ & $3.0 \mathrm{a} *_{-}$ \\
\hline T2 $(20 \mathrm{~cm})$ & $2640 \mathrm{~b} * * *$ & $106.3 \mathrm{~b} * *$ & $2.4 \mathrm{~b} *$ \\
\hline T3 $(40 \mathrm{~cm})$ & $2220 \mathrm{c} * * *$ & $44.7 \mathrm{c} *$ & $1.5 \mathrm{c} *$ \\
\hline $\mathrm{T} 4(60 \mathrm{~cm})$ & $1980 \mathrm{~d} * * *$ & $1.3 \mathrm{~d} *$ & $0 \mathrm{~d} *_{-}$ \\
\hline T5 $(80 \mathrm{~cm})$ & $1680 \mathrm{e}^{* * *}$ & $0 \mathrm{e}^{*}$ & $0 \mathrm{~d} *_{-}$ \\
\hline T6 $(100 \mathrm{~cm})$ & $110 \mathrm{f} * *$ & $0 \mathrm{e}^{*}$ & $0 \mathrm{~d} *_{-}$ \\
\hline $\mathrm{T} 7(120 \mathrm{~cm})$ & $80 \mathrm{fg} * *$ & $0 \mathrm{e}^{*}$ & $0 \mathrm{~d} *_{-}$ \\
\hline $\mathrm{T} 8(140 \mathrm{~cm})$ & $74 \mathrm{fg} * *$ & $0 \mathrm{e}^{*}$ & $0 \mathrm{~d} *_{-}$ \\
\hline T9 $(160 \mathrm{~cm})$ & $70.8 \mathrm{fg} * *$ & $0 \mathrm{e}^{*}$ & $0 \mathrm{~d} *$ \\
\hline $\mathrm{T} 10(180 \mathrm{~cm})$ & $22 \mathrm{~g} *$ & $0 \mathrm{e}^{*}$ & $0 \mathrm{~d} *_{-}$ \\
\hline T11 (200 cm) & $19.67 \mathrm{gh} *$ & $0 \mathrm{e}^{*}$ & $0 \mathrm{~d} *$ \\
\hline $\mathrm{T} 12(220 \mathrm{~cm})$ & $14.67 \mathrm{gh} *$ & $0 \mathrm{e}^{*}$ & $0 \mathrm{~d} *_{-}$ \\
\hline $\mathrm{T} 13(240 \mathrm{~cm})$ & $<1 \mathrm{~h} *_{-}$ & $0 \mathrm{e}^{*}$ & $0 \mathrm{~d} *_{-}$ \\
\hline $\mathrm{T} 14(260 \mathrm{~cm})$ & $<1 \mathrm{~h} *$ & $0 \mathrm{e}^{*}$ & $0 \mathrm{~d} *_{-}$ \\
\hline $\mathrm{T} 15(180 \mathrm{~cm})$ & $<1 \mathrm{~h} *$ & $0 \mathrm{e}^{*}$ & $0 \mathrm{~d} *$ \\
\hline $\mathrm{T} 16(300 \mathrm{~cm})$ & $<1 \mathrm{~h} *$ & $0 \mathrm{e}^{*}$ & $0 \mathrm{~d} *_{-}$ \\
\hline C.V $(\%)$ & 5.7 & 11.6 & 25.1 \\
\hline LSD at 0.05 & $68.7 ! ! !$ & $3.2 ! ! !$ & $0.2 ! ! !$ \\
\hline
\end{tabular}

$\mathrm{WDPT}=$ water drop penetration time, $*_{-}=$non-water repellent $(\mathrm{WDPT}<5 \mathrm{sec}),{ }^{*}=$ slightly water repellent $(\mathrm{WDPT}=5-60 \mathrm{sec}), * *=$ strongly water repellent $(\mathrm{WDPT}=60-600), * * *=$ severely water repellent $(\mathrm{WDPT}=$ $600-3600 \mathrm{sec}$ ).

Mean values followed by the same letters are not significantly different at 0.05 level LSD test. !!! = Significant at the 0.001 level.

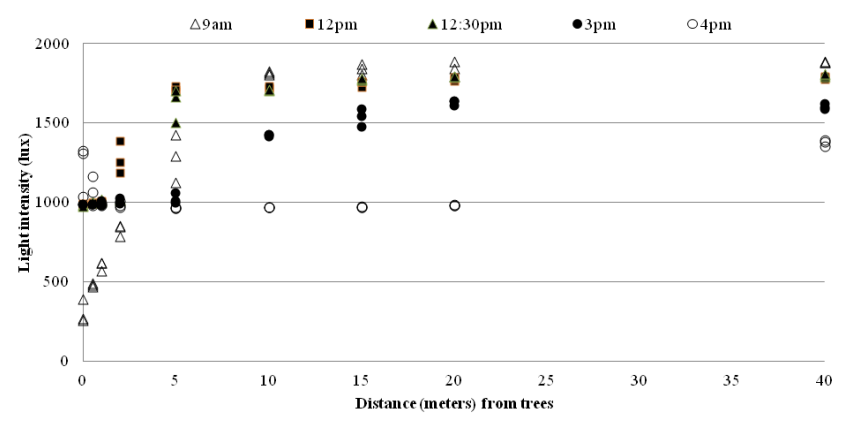

Fig. 6. Light intensity values at different times within a day and at increasing distances from the Eucalyptus tree plantations. The measurements were taken in west direction at 9:00 and 12:00am, north direction at 12:30pm and east direction at 3:00 and 4:00pm. All data points graphed.

Table 5. Mean Eucalyptus tree root distribution at different distances and depths (no. $0.2 \mathrm{~m}^{2}$ ).

\begin{tabular}{lccc}
\hline $\begin{array}{l}\text { Sampling } \\
\text { depth }(\mathrm{cm})\end{array}$ & \multicolumn{3}{c}{$\begin{array}{c}\text { Root distribution }\left(\text { no. } 0.2 \mathrm{~m}^{2}\right) \text { at different } \\
\text { sampling distances from Eucalyptus }\end{array}$} \\
& 1 & 5 & 10 \\
\hline 20 & 22.7 & 135.0 & 13.3 \\
40 & 26.3 & 144.0 & 14.7 \\
60 & 37.7 & 177.0 & 16.3 \\
\hline
\end{tabular}

\section{DISCUSSION}

The three different plantations of Eucalyptus spp. and Croton macrostachyus were grown on three different clay loam soils (Table S4) with medium organic matter content (Fig. S1), low pH (Fig. S2) and low organic matter, respectively. The results of the sampling from the fields bordered by Eucalyptus and within the Eucalyptus stands were remarkably similar. The root density was greatest at $5 \mathrm{~m}$ from the tree (Table 5), and the macronutrients (with the exception of potassium) were most depleted at this point. Moisture contents were also the lowest here, but not always statistically significant (Fig. 4). Soil pH (Fig. S2), organic matter (Fig. S1), exchangeable K and bulk density were not affected by Eucalyptus. Yield and biomass of maize were most reduced near the Eucalyptus stand (Fig. 7C). This was not only due to the effect of the Eucalyptus on the soil, but also because the light intensity was greatly reduced as well (Fig. 6) in accordance with findings of Agele et al. (2007) and Kotowski et al. (2000). The competition of Eucalyptus for nutrients can be overcome somewhat by adding fertilizers (Ayoola and Makinde, 2008; Cahill, 1999).

The reduced moisture availability near the Eucalyptus stands (Fig. 4 and Fig. 5) is in partial agreement with those of Kidanu (2004) who reported that irrespective of crop species, less water remained in the soil in the tree-crop system than in the sole cropping. In our case when there is sufficient rain, Eucalyptus trees do not affect the moisture content, but only when rainfall decreases Eucalyptus dries out the soil faster. This is in accordance with Susiluoto and Berninger (2007) who reported that Eucalyptus trees have roots that are well developed in the dry areas and enable them to use the water stored in the soil during the dry season. In the semi humid highlands during the rainy season, there is sufficient water for both crops and trees and other factors (such as shading and reduced nutrient status) are responsible for the decrease in yield (Table 5).

In accordance with findings of Abelho and Graça (1996), Eucalyptus trees cause soil hydrophobicity up to $2 \mathrm{~m}$ from the tree during the dry season through leaf litter incorporation at the surface of the soil (Table 4). Hydrophobicity not only affects water infiltration, but also can affect soil microorganism activity and plant growth (Florenzano, 1957). 
Total nitrogen content in the plough zone from 0 to $20 \mathrm{~cm}$ depth at all distances was in the very high range (Fig. 3A). Near the Eucalyptus stand, this might be due to its allelopathic effect, which prevents $\mathrm{N}$ uptake by the plants (Bernhard-Reversat, 1987). The available phosphorus content (Fig. 3B) was in the very low range $\left(<5 \mathrm{mg} \mathrm{kg}^{-1}\right)$ because the acidic soil fixed the phosphorus. Similar to other Ethiopian soils, we found that the exchangeable calcium and potassium were all in the high range (Ilaco, 1985)
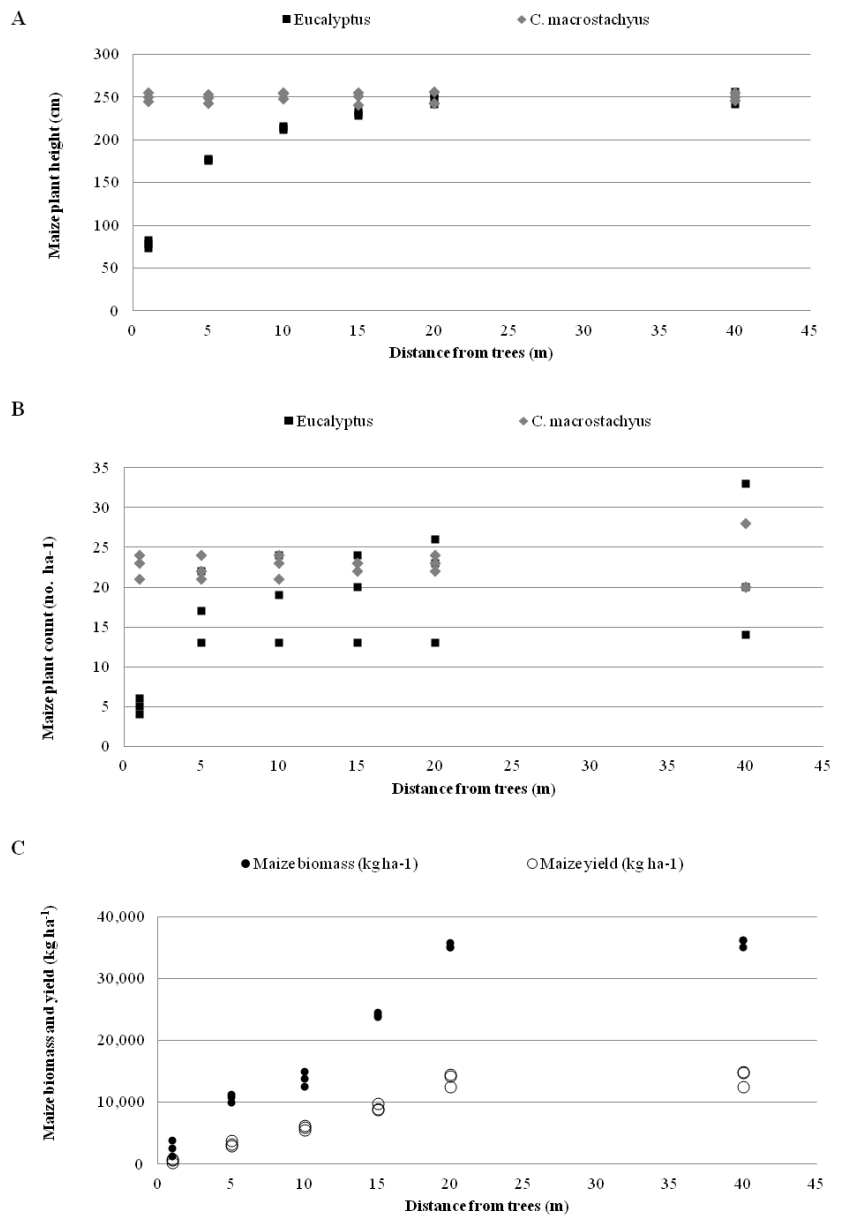

Fig. 7. Comparison of maize plant count (A) and plant height (B) in crop fields adjacent to Eucalyptus and C. macrostachyus tree plantations, and biomass and grain yield (C) of maize in fields adjacent to Eucalyptus plantations. All samples from each distance and field were graphed.

In the Koga Watershed, trees like Acacia species serve as shade for coffee and allow for the undergrowth of grasses, shrubs and ferns. In addition there are other manageable, fast maturing and widely adaptable leguminous tree species (Leucaena leucocephala, Prosopis juliflora and Albizia procera), which improve the productivity of the adjacent plantation (Mahmud et al., 2005). In contrast, Eucalyptus species have less understory vegetation (Fig. S4, Fabiã et al., 2002). The good performance of Leucaena and Acacia species) is due to the absence of competition for resources with the understory plants (such as coffee) due to a deeper rooting system (Lehmann, 2003), nitrogen fixation (Ramadhanil et al., 2008) and a diverse and rich microbial habitat (Dupuy and Dreyfus, 1992; Parker and Brown, 1999). This is not true for Eucalyptus since local farmers tried and failed growing coffee under its shade. In addition, Eucalyptus leaf extracts inhibited the germination of several plants (Watson, 2000) and reduces seedling emergence of maize (El-Khawas and Shehata, 2005). Therefore, Eucalyptus trees have drawbacks to improving the performance of the undergrowth vegetation. However, because of its predominance in the landscape, the overall economic benefits of Eucalyptus must outweigh the benefits of increased undergrowth of indigenous trees.

\section{CONCLUSIONS}

Farmers perceived that Eucalyptus plantation depreciates the potential of the environment even though they continue to plant the trees because of the relative short time required to produce wood biomass for fuel, construction and cash.

Experimentally, it was proven that the poor performances of the adjacent plants, particularly maize and undergrowth plants, were due to light, water and nutrients (total nitrogen, available phosphorus and exchangeable calcium) competition and soil water repellency. Based on these results, the impacts of Eucalyptus on soil properties and moisture content are limited to a great extent to $20 \mathrm{~m}$ away from the tree. Since Eucalyptus spp. are fast growing, and deep and dense rooted, the reduction and drying out of previously functional water stores nearby in the watershed is a result of its great water suction ability in addition to it causing water repellency in the soil and poor undergrowth, both reducing infiltration and the water table. Thus, the potential ecosystem will be exhausted in the future because of the negative impact of Eucalyptus.

Ultimately, farmers should change their management within this $20 \mathrm{~m}$ zone between crops and trees. Crops (maize and undergrowth) should be cultivated at distances greater than $15-$ $20 \mathrm{~m}$ from Eucalyptus stands. For the sustainability and efficiency of the Koga irrigation project, it is important to note that, according to the respondents in the survey, Eucalyptus is reducing the quantities of water available. This is important when we consider that this limits the amount of water available for irrigation. Therefore, from the food security point of view, priority should be given to crop production. In other words, productive lands should be left for crops, and Eucalyptus trees should be limited to marginal lands, such as wetlands. This too has been suggested by the farmers for better ecosystem and agricultural land management.

\section{REFERENCES}

Abelho, A., Graça, M.A.C., 1996. Effect of Eucalyptus afforestation on leaf litter dynamics and macroinvertebrate community structure of streams in central Portugal, Portugal. Hydrobiologia, 324, 195-204.

Agele, S.O., Maraiyesa, I.O., Adeniji, I.A., 2007. Effects of variety and raw spacing on radiation interception, partitioning of dry matter and seed set efficiency in late season sunflower (Helianthus annuus L.) in a humid zone of Nigeria. African J. Agric. Res., 3, 80-88.

Ayoola, O.T., Makinde, E.A., 2008. Performance of green maize and soil nutrient changes with fortified cow dung, Nigeria. African Journal of Plant Science, 2, 19-22.

Bayabil, H.K., Tilahun, S.A., Collick, A.S., Steenhuis, T.S., 2010. Are runoff processes ecologically or topographically driven in the Ethiopian Highlands? The case of the maybar. Ecohydrology, 3, 4, 457-466.

Bernhard-Reversat, F., 1987. Soil nitrogen mineralization under a Eucalyptus plantation a natural Acacia forest in Senegal. Forest Ecology and Management, 23, 233-244.

Bernhard-Reversat, F., 1999. The leaching of Eucalyptus hybrids and Acacia auriculiformis leaf litter: laboratory exper- 
iments on early decomposition and ecological implications in Congolese tree plantations, France. Applied Soil Ecology, $12,251-261$.

Blake, G.R., 1965. Bulk density. In Black C.A. (Ed). Methods of soil analysis Agron. Part I, No. 9. Am. Soc. Agron. Madison, Wisconsin, USA.

Cahill J.F., 1999. Fertilization effects on interactions between above-and-belowground competition in an old field. Ecology, $80,466-480$.

Cohen, J.B., 1910. Practical Organic Chemistry. Macmillan and Co., Limited, London.

Dekker, L.W., Ritsema, C.J., 1995. Fingerlike wetting patterns in two water-repellent loam soils. J. Environ. Qual., 24, 324 -333 .

Dupuy, N.C., Dreyfus, B.L., 1992. Bradyrhizobium populations occur in deep soil under the leguminous tree Acacia albida. Appl. Environ. Microbiol. 58, 2415-2419.

El-Amin, E.A., Diab, I.E., Ibrahim, S.I., 2001. Influence of Eucalyptus on some physical and chemical properties of a soil in Sudan. Commun. Soil Plant Anal., 32, 2267-2278.

El-Khawas, S.A., Shehata, M.M., 2005. The allelopathic potentialities of Acacia nilotica and Eucalyptus rostrata on monocot (Zea mays L.) and dicot (Phaseolus vulgaris L.) plants. Biotechnology, 4, 23-34.

Fabiã, A., Martins, M.C., Cerveira, C., Santos, C., Lousa, M., Madeira, M., Correia, A., 2002. Influence of soil and organic residue management on biomass and biodiversity of understory vegetation in a Eucalyptus globulus Labill plantation. Forest Ecology and Management, 171, 87-100.

Florenzano, G., 1957. Richerche sui terreni coltivati ad eucalitti. II Recherche Microbiologiche e Biochimiche. Centro di Sperimentazione Agricola e Forestale, Pub I, 133-152. Laimburg, Italy.

Gindaba, J., Rozanov, A., Negash, L., 2004. Response of seedlings of two Eucalyptus and three deciduous tree species from Ethiopia to severe water stress. Forest Ecology and Management, 201, 119-129.

Ilaco, B.V., 1985. Agricultural Compendium. Elsevier, Amsterdam. The Netherlands.

Jagger, P., Pender, J., 2003. The role of trees for sustainable management of less-favored lands: the case of Eucalyptus in Ethiopia. Forest Policy and Economics, 5, 83-95.

Holgén, P., Svensson, M., 1990. Loss of inorganic nutrients by whole tree utilization for firewood in Ethiopia. A minor field study. Working Paper - International Rural Development Centre, Swedish University of Agricultural Sciences, 150, 59.

Kidanu, S. 2004. Using Eucalyptus for soil and water conservation on the highland vertisols of Ethiopia. Tropical Resource Management Papers 52. Wageningen University Wageningen. The Netherlands.
Kidanu, S., Mamo, T., Stroosnijder, L., 2005. Biomass production of Eucalyptus boundary plantations and their effect on crop productivity on Ethiopian highlands vertisols, Ethiopia. Agroforestry Forum, 63, 281-290.

Klute, A., 1965. Water holding capacity. In C.A. Black (Ed.). Methods of soil analysis. Agron. Part I, No. 9, Am. Soc. Agron. Madison, Wisconsin, USA.

Kotowski, W., van Andel, J., van Diggelen, R., Hogendorf, J., 2000. Response of fen plant species to groundwater level and light intensity. Plant Ecology, 155, 147-156.

Lane, P.N.J., Morris, J., Ningnan, Z., Guangyi, Z., Guoyi, Z., Daping, X., 2004. Water balance of tropical Eucalyptus plantations in south-eastern China. Agricultural and Forest Meteorology, 124, 253-267.

Lehmann, J., 2003. Subsoil root activity in tree-based cropping systems. Plant and Soil, 255, 319-331.

Mahmud, S., Hoque, R.A.T.M., Mohiuddin, M., 2005. Nodulation behavior and biomass productivity of three leguminous plant species at nursery stage in Chittagong University soils. Research Journal of Agriculture and Biological Sciences, 1, 89-93.

Olsen, S.R., Cole, C.V., Watanabe, F.S., Dean, L.A., 1954. Estimation of available phosphorus in soil by extraction with sodium bicarbonate. USDA Circular, 939, 1-19.

Pankhurst, R.K., 1961. An Introduction to the Economic History of Ethiopia. Lalibela House, London.

Parker, G.G., Brown, J.M., 1999. Forest canopy stratification Is it useful? The American Naturalist, 155, 473-484.

Ramadhanil, T.S.S., Setiadi, D., 2008. Structure and composition of understory plant assemblages of six land use types in the lore Lindu National Park, Central Sulawesi, Indonesia. Bangladesh J. Plant Taxon, 15, 1-12.

Rowell, D.L., 1994. Soil Science: Methods and Applications. Addison Wesley Longman Limited. England.

Sahlemeden, S., Taye, B., 2000. Procedure for soil and plant analysis. National Soil Research Center, Ethiopian Agricultural Research Organization, Addis Ababa, Ethiopia.

Susiluoto, S., Berninger, F., 2007. Interactions between Morphological and physiological drought responses in Eucalyptus microtheca. Silva Fennica, 41, 221-233.

Walkley, A., Black, I.A., 1934. An examination of Degtjareff method for determining soil organic matter and a proposed modification of the chromic acid titration method. Soil Sci., 37, 29-37.

Watson, K., 2000. The effect of Eucalyptus and Oak leaf extracts on California Native plants, California. World Soil Resources, Reports 94, FAO, 2001.

Received 15 October 2012 Accepted 11 December 2012

Note: Supplementary Tables (S1-S4) and Figures (S1-S3), as well as colour version of Figures 1 and 2 can be found in the web version of this article. 


\section{SUPPLEMENTARY MATERIAL}

Table S1. Activities performed by a farmer on his land in the Koga watershed $(\mathrm{N}=25)$.

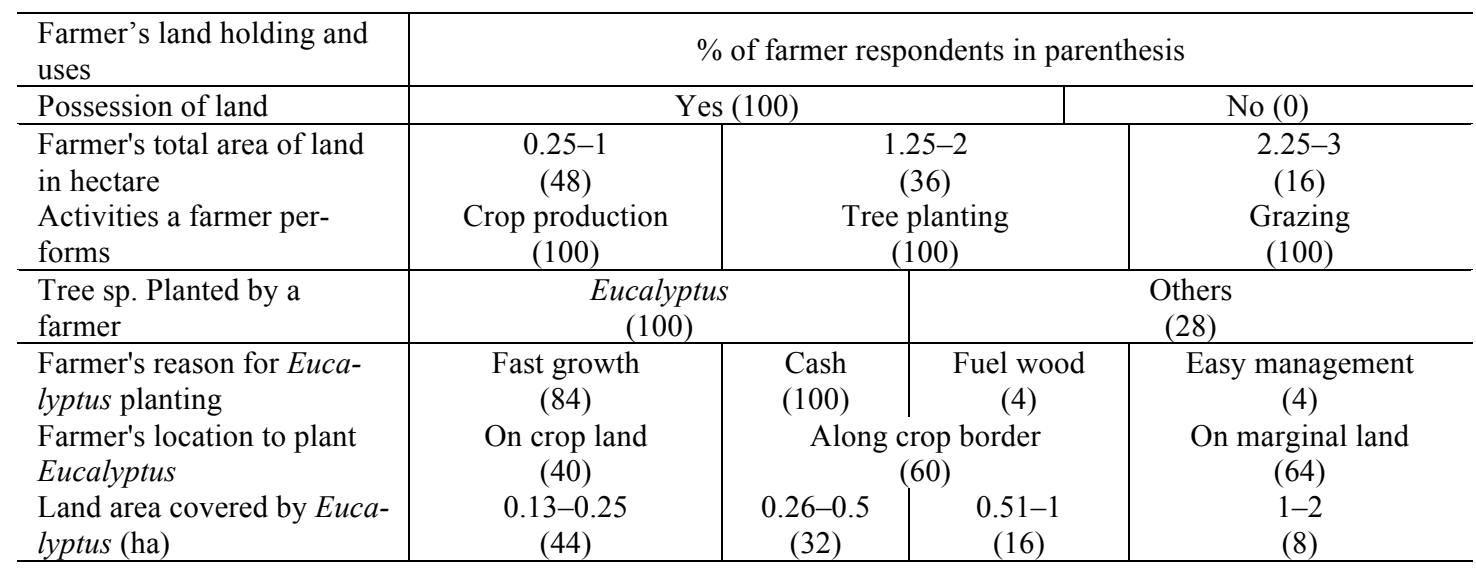

Table S2. Farmers' perception about environmental impact of Eucalyptus plantation in the Koga Watershed $(\mathrm{N}=25)$

\begin{tabular}{|c|c|c|c|c|c|c|}
\hline Impact of Eucalyptus & \multicolumn{6}{|c|}{$\%$ of farmer respondents in parenthesis } \\
\hline Effect on crop production, soil and water & \multicolumn{3}{|c|}{$\begin{array}{l}\text { Yes } \\
(100) \\
\end{array}$} & \multicolumn{3}{|c|}{$\begin{array}{l}\text { No } \\
(0) \\
\end{array}$} \\
\hline Resistance difference with crops & \multicolumn{3}{|c|}{ Yes (56) } & \multicolumn{3}{|c|}{ No (44) } \\
\hline Resistant crops & $\begin{array}{l}\text { Maize } \\
(20)\end{array}$ & $\begin{array}{l}F . \text { millet } \\
\text { (4) }\end{array}$ & $\begin{array}{l}\text { teff } \\
(28)\end{array}$ & $\begin{array}{c}\text { noug } \\
\text { (12) }\end{array}$ & $\begin{array}{l}\text { bean } \\
(4)\end{array}$ & $\begin{array}{l}\text { others } \\
(8)\end{array}$ \\
\hline Susceptible crops & $\begin{array}{c}\text { Maize } \\
(80)\end{array}$ & $\begin{array}{l}\text { F. millet } \\
(96)\end{array}$ & $\begin{array}{l}\text { teff } \\
(56)\end{array}$ & $\begin{array}{l}\text { noug } \\
(52)\end{array}$ & $\begin{array}{l}\text { bean } \\
(44)\end{array}$ & $\begin{array}{l}\text { others } \\
(44)\end{array}$ \\
\hline
\end{tabular}

Table S3. Mechanisms and conditions by which Eucalyptus plantation affects the ecosystem $(\mathrm{N}=25)$ according to farmers' perceptions.

\begin{tabular}{|c|c|c|c|c|c|}
\hline Mechanisms & \multicolumn{5}{|c|}{$\%$ of farmer respondents in parenthesis } \\
\hline $\begin{array}{l}\text { Affect on crop pro- } \\
\text { duction }\end{array}$ & $\begin{array}{l}\text { Shading } \\
\text { effect } \\
(4)\end{array}$ & $\begin{array}{l}\text { Nutrient compe- } \\
\text { tition } \\
(28)\end{array}$ & $\begin{array}{l}\text { Moisture com- } \\
\text { petition } \\
(28)\end{array}$ & $\begin{array}{l}\text { Seedling } \\
\text { thinning } \\
(56)\end{array}$ & $\begin{array}{l}\text { Affecting grain } \\
\text { filling } \\
\text { (8) }\end{array}$ \\
\hline $\begin{array}{l}\text { Causing alteration } \\
\text { of soil property }\end{array}$ & \multicolumn{2}{|c|}{$\begin{array}{c}\text { Causing unfertility } \\
(8)\end{array}$} & \multicolumn{2}{|c|}{$\begin{array}{c}\text { Changing soil color to red } \\
(4)\end{array}$} & $\begin{array}{l}\text { Drying out } \\
(92)\end{array}$ \\
\hline $\begin{array}{l}\text { Effect on water } \\
\text { bodies }\end{array}$ & \multicolumn{3}{|c|}{ Sucking much water (96) } & \multicolumn{2}{|c|}{ Have no idea (4) } \\
\hline $\begin{array}{l}\text { Presence of dried up } \\
\text { water bodies }\end{array}$ & \multicolumn{2}{|r|}{$\begin{array}{l}\text { Yes } \\
(80)\end{array}$} & & \multicolumn{2}{|c|}{$\begin{array}{l}\text { No } \\
(20)\end{array}$} \\
\hline
\end{tabular}

Table S4. Mesm soil fractions and textural classes of the different sites at different sampling distances from Eucalyptus hedge rows.

\begin{tabular}{|c|c|c|c|c|c|c|c|c|}
\hline & \multicolumn{8}{|c|}{ Percent soil texture at sampling point distances from tree stands } \\
\hline & $0.5 \mathrm{~m}$ & $1 \mathrm{~m}$ & $2 \mathrm{~m}$ & $5 \mathrm{~m}$ & $10 \mathrm{~m}$ & $15 \mathrm{~m}$ & $20 \mathrm{~m}$ & $40 \mathrm{~m}$ \\
\hline Sand & 27.0 & 30.7 & 27.7 & 29.7 & 30.3 & 31.7 & 32.3 & 32.0 \\
\hline Silt & 36.0 & 31.7 & 33.7 & 32.3 & 33.0 & 29.7 & 30.3 & 33.7 \\
\hline Clay & 37.0 & 37.7 & 38.7 & 38.0 & 36.7 & 38.7 & 37.3 & 34.3 \\
\hline Class & Clay loam & $\begin{array}{l}\text { Clay } \\
\text { loam }\end{array}$ & $\begin{array}{l}\text { Clay } \\
\text { loam }\end{array}$ & $\begin{array}{l}\text { Clay } \\
\text { loam }\end{array}$ & $\begin{array}{l}\text { Clay } \\
\text { loam }\end{array}$ & $\begin{array}{l}\text { Clay } \\
\text { loam }\end{array}$ & $\begin{array}{l}\text { Clay } \\
\text { loam }\end{array}$ & $\begin{array}{l}\text { Clay } \\
\text { loam }\end{array}$ \\
\hline
\end{tabular}




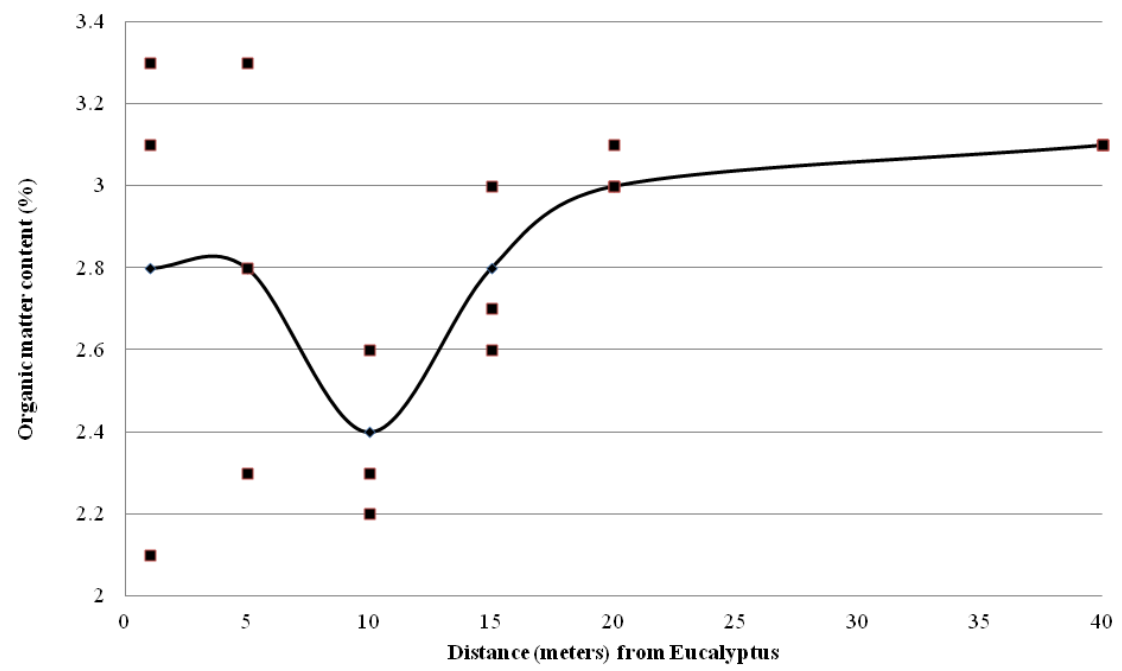

Fig. S1. Organic matter values comparison along distance from Eucalyptus stand in the plough depth. Mean values are represented by the line. All samples from each distance and field were graphed.

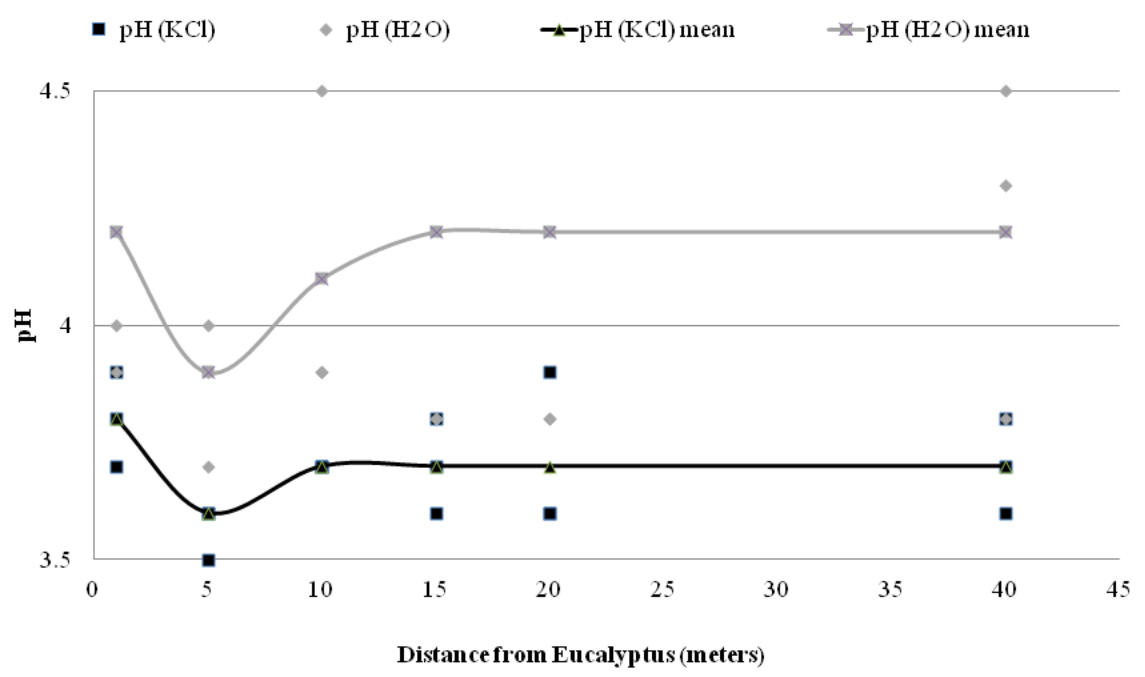

Fig. S2. pH values at increasing distances from Eucalyptus stands. The lines represent the mean of the samples graphed. All samples from each distance and field were graphed.

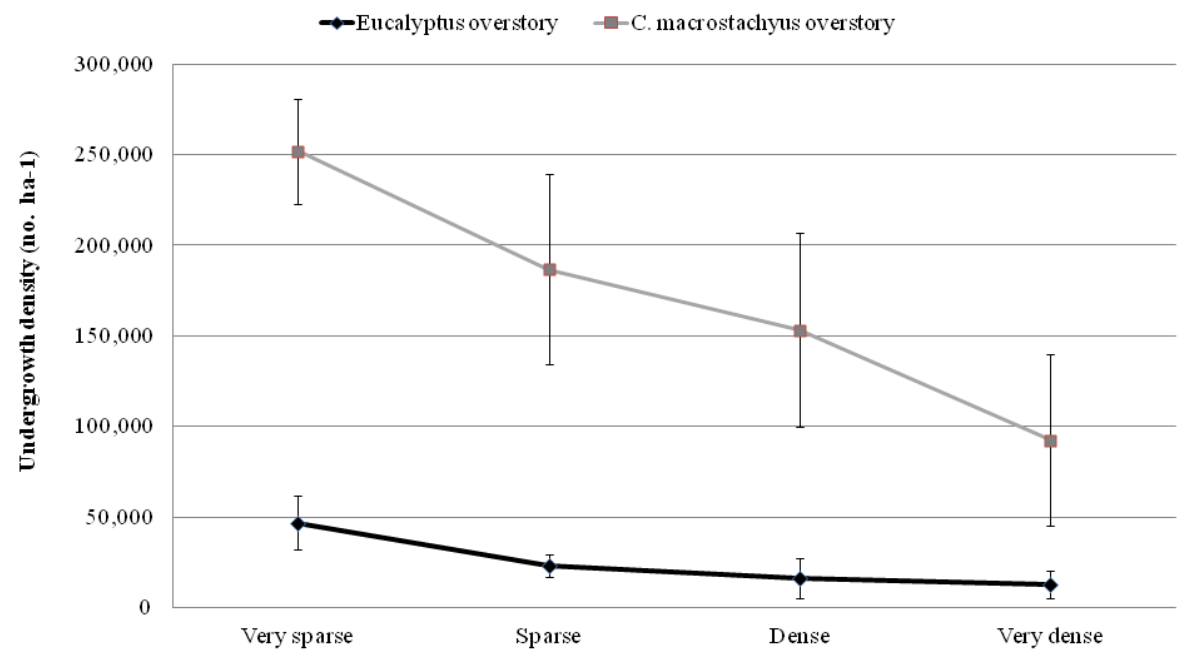

Fig. S3. Comparison of coffee undergrowth density (no. ha ${ }^{-1}$ ) values between plantations of Eucalyptus and C. macrostachyus, the common coffee garden shade. 